Engineering Sustainability

Volume 170 Issue ES1

A geographic information method for managing urban energy use

Gagliano, Nocera, Detommaso and Spataru
Proceedings of the Institution of Civil Engineers

Engineering Sustainability 170 February 2017 Issue ES

Pages 19-32 http://dx.doi.org/10.1680/jensu.15.00052

Paper 1500052

Received 30/09/2015 Accepted 15/03/2016

Published online 19/04/2016

Keywords: energy/management/public policy

\title{
A geographic information method for managing urban energy use
}

Antonio Gagliano MSc, PhD

Assistant Professor, Department of Industrial Engineering, University of Catania, Catania, Italy (corresponding author: agagliano@dii.unict.it)

Francesco Nocera MSc, PhD

Assistant Professor, Department of Industrial Engineering, University of Catania, Catania, Italy

\section{Maurizio Detommaso MSc}

Department of Industrial Engineering, University of Catania, Catania, Italy

Catalina Spataru MSc, PhD

Senior Researcher, UCL Energy Institute, University College London, London, UK

This paper presents a geographical information method to support urban-level energy policies. It proposes using a geographical information system to store, display, edit, share and analyse geographical information for territorial decision-making. The method was used to help develop a sustainable energy action plan for the municipality of Randazzo in Sicily, Italy, by providing an accurate representation of actual energy consumption. Based on this case study, the use of a geographical information system appears to be a suitable support tool for both developing and managing sustainable energy action plans, regardless of the geographical area or context. This method will help municipalities estimate and monitor the energy consumption of residential, commercial and industrial buildings and, by taking into account the approaches of different stakeholders, help develop more accurate models for reducing urban carbon dioxide emissions.

\section{Introduction}

EU leaders have committed to transforming Europe into a highly energy-efficient, low-carbon dioxide economy. After the adoption of the EU climate and energy package, in 2008, the European Commission launched the Covenant of Mayors (CoM) to endorse and support the efforts deployed by local authorities in the implementation of sustainable energy policies (EC, 2002; Energy Cities, 2010).

As of mid-May 2014, 5296 local authorities signed the CoM, for a total of c. 160 million inhabitants in the EU-28 and c. 186 million inhabitants in the whole initiative. It is important to highlight that the majority of signatories with a submitted sustainable energy action plan (SEAP) are small and medium towns, representing $88 \%$ of the total number of signatories of the sample (European Commission, 2016).

Based on the estimation in SEAPs of the CoM signatories as of mid-May 2014, $18 \%$ of the final energy consumption by 2020 will be produced locally from renewable sources and by efficient energy generation technologies (district heating and combined heat and power (CHP) plants) (European Commission, 2016). In the CoM, the data set as of 13 May 2014 is 1837 in Italy. This represents $54 \%$ of the signatories in the EU-28. Despite the great membership of the Italian community, the values of the estimated energy savings per capita by $2020(2.91 \mathrm{MWh} /$ capita $)$ and the estimated greenhouse gas (GHG) emission reduction per capita by $2020(1.06 \mathrm{t}$ carbon dioxide equivalent/capita) are below the European averages of $3.51 \mathrm{MWh} /$ capita and $1.54 \mathrm{t}$ carbon dioxide equivalents/capita respectively.
Fundamentally, three main parts constitute a SEAP: baseline emission inventory (BEI), actions and target (see Figure 1).

The BEI is the inventory of annual carbon dioxide emissions relating to energy end uses in a city territory. The actions are a set of comprehensive actions with estimated impacts, while vision, objectives and target define an objective to achieve emissions reduction. Sectors such as the residential, tertiary and municipal buildings and equipment/facilities and transport are the key sectors in the CoM initiative.

The actions of the SEAP have to pertain to the following sectors: built environment; municipal infrastructure (heating, cooling, public lighting); land use and urban planning; renewable energy sources; public and private transport policies and urban mobility.

Consequently, local communities have the opportunity to impact on the climate change by starting a new energy policy based on energy saving, efficiency and renewable energy sources in order to diminish emissions of carbon dioxide.

The GHG emission reduction per sector, as reported in SEAPs, highlights that the biggest reduction of GHG emissions (44\%) is estimated to take place in the building sector; followed by the transport sector, with a share of $19 \%$; local electricity production, with $14 \%$; and local district heating and CHPs, with $9 \%$. Other sectors include measures planned in areas of public procurement, land use planning and working with citizens (CoM, 2016). 
A geographic information method for

managing urban energy use

Gagliano, Nocera, Detommaso and Spataru

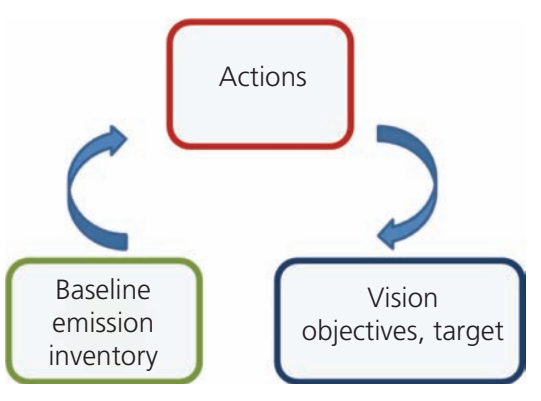

Figure 1. Structure of a SEAP

The biggest problem for the energy analysis of large urban areas is the scarcity of energy consumption measurements. Therefore, a useful tool that can help to develop and monitor the SEAP is the geographical information system (GIS) platform, which makes possible the management of available data on energy. GIS database systems aim at storing, displaying, editing, sharing and analysing geographical information for territorial decisionmaking.

The GIS method has been valued for improving communication and collaboration in decision-making, effectively managing resources and assets, enhancing the efficiency of workflows, improving the accessibility of information and generally offering tangible cost savings to small and large organisations.

In the last 10 years, many studies have used GIS platforms for energy and environmental prediction models (Jones et al., 2001; Thuvander, 2002; Tornberg and Thuvander, 2005).

A GIS-based approach has been used for identifying and quantifying the effect of local constraints on the renewable energy potential (Ramachandra and Shruthi, 2007) and to facilitate the feasibility analysis of investments for policymakers, investors and energy planners in a given region (Sun et al., 2013). GIS-based tools have been developed for evaluating the local GHG emissions (Asdrubali et al., 2013), the energy yield of micro-wind turbine (Gagliano et al., 2013a) and photovoltaic (PV) systems (Gagliano et al., 2013b) in urban areas.

Further, energy consumption in the buildings sector and their classification has been widely studied (Comodi et al., 2011; Dall'O' et al., 2012; Dascalaki et al., 2010; Theodoridou et al., 2011; Tommerup and Svendsen, 2006).

Other studies have investigated possible energy policies to reduce the final energy consumption within the boundaries of a municipality or a region from all public and private sectors responsible for energy consumption (Caputo et al., 2013). Several municipalities have developed (Brandoni and Polonara, 2012; Fiaschi et al., 2012; Hou et al., 2011) an action plan to reduce energy consumption and integrate renewable energy sources in buildings and utilities of a small Italian city.
This study foresees the application of the GIS platform as a support tool for preparing and managing the SEAP of a municipality.

The building stock and infrastructure energy requirements are stored in the GIS database and periodically updated for estimating, monitoring and verification of any reductions in energy consumption and carbon dioxide emissions. In such a way, it will be possible to display, share, analyse and monitor the state of actuation of the SEAP actions.

\section{Methodology}

Generally, it is very difficult to have a full picture of the actual state of the requirements of the urban energy system and residential, tertiary and municipal buildings equipment/facilities and transport.

Data, mainly coming from legal registers and energy bill monitoring, are often dispersed, for historical reasons, among distinct administrative office and service providers. In the past, the information has not necessarily been collected purposefully, making it awkward to use.

In this context, the GIS provides a geo-referenced representation of the municipality territory that can be enhanced with data on the actual energy requirements of the municipality and the local production of energy.

Further, the GIS platform allows updating and managing the gathered data in order to monitor and evaluate the progress of the SEAP objectives, which is an important step for ensuring the project will reach its target. Therefore, the GIS database is not only useful for assessing the urban energy inventory at the present state, but also for the evaluation of competing scenarios and the optimal integration of the energy conversion technologies. Moreover, the GIS system allows using data carried out by other software; as an example, there is a possibility to calculate the energy yields of micro-wind turbines (Gagliano et al., 2013a).

\subsection{Source and availability of data}

One of the main tasks in preparing a SEAP is the research on data on the building stock, the energy consumptions of the different sectors and the local energy resources.

Aerial photographs play an important role in GIS data acquisition and visualisation as they provide a basis for gathering spatial information. The aerial photographs must be prepared in a way that removes distortion from the image through the so-called orthorectification. An orthophotograph has the same scale throughout and can be used as a map.

The digital elevation model (DEM) of most regions of the world is available (e.g. the digital terrain model of the region Sicily with a resolution distance of $2 \mathrm{~m}$ DEM can be downloaded from the website of Sistema Informativo Territoriale Regionale (SITR, 2016)). 
Obtaining suitable information on the building's energy performance and consumption are essential for quality control management and efficiency in the SEAP.

Usually, data on the building stock and commercial, tertiary and artisanal activities can be retrieved through the office for national statistics (e.g. in Italy through the Istituto Nazionale di Statistica national census database (Istat, 2016)). The national census database provides an accurate population count, update and review of civil registry data, calculates the legal population and gathers information on the number and structural characteristics of housing and buildings.

The building map can be obtained from the housing and residential department. Thus, layout (area, perimeter and height of buildings) and destination of use of buildings can be retrieved from this source. Energy building consumptions and size and energy yield of renewable energy plants can be retrieved through the energy cadastral office (e.g. in Sicily by the Catasto Energetico Fabbricati (Cefa, 2016)).

The construction characteristics of buildings such as surface area, heated volume, number of floors and the form factor $(S / V)$ - that is the ratio between external surface $(S)$ of the building envelope and heated volume $(V)$ - can be extracted from different sources: orthophotograph, the municipality's technical department (TDM), cadastral map, and so on.

The main energy usages in buildings are heating, cooling, ventilation and humidity control, production of sanitary hot water, lighting, and electrical appliances. The energy consumptions for space heating and domestic hot water (DHW) production can be calculated considering the procedure defined by national

Field Description Unit Information

\begin{tabular}{|c|c|c|c|}
\hline 01 & Building ID & - & ID number of a building \\
\hline 02 & Cadastral reference & - & Information detected from cadastral maps \\
\hline 03 & Building typology & - & Information detected from the TDM or direct survey \\
\hline 04 & Function end use & - & Type of destination (e.g. residential, tertiary, commercial) \\
\hline 05 & Number of inhabitants & - & Information detected from the civil registry \\
\hline 06 & Construction period & - & Construction period of the building \\
\hline 07 & Roof type & - & Information detected from orthophotograph \\
\hline 08 & Roof orientation & - & Information detected from orthophotograph \\
\hline 09 & Number of floors & - & Information detected from the TDM about status \\
\hline 10 & Height & $\mathrm{m}$ & Information detected from the TDM about status or from survey \\
\hline 11 & Roof area & $m^{2}$ & Calculated by tools \\
\hline 12 & Volume & $\mathrm{m}^{3}$ & Calculated by tools \\
\hline 13 & Building envelope surface & $m^{2}$ & Calculated by tools \\
\hline 14 & Window surface & $m^{2}$ & Available field for entering data from survey \\
\hline 15 & Thermal dispersion surface & $m^{2}$ & Calculated by tools \\
\hline 16 & $S / \mathrm{V}$ & $m^{-1}$ & Calculated by tools \\
\hline 17 & Heat generator & $\mathrm{kW}$ & Available field for entering data from survey \\
\hline 18 & Solar thermal plant & $m^{2}$ & Available field for entering data from survey \\
\hline 19 & Solar PV plant & $\mathrm{kWp}$ & Available field for entering data from survey \\
\hline 20 & Micro-wind plant & $\mathrm{kW}$ & Available field for entering data from survey \\
\hline 21 & Solar radiation & $\mathrm{kWh} / \mathrm{m}^{2}$ & Available field for entering data on solar radiation tool \\
\hline 22 & Wind velocity & $\mathrm{m} / \mathrm{s}$ & Available field for entering data from survey (Weibull distribution) \\
\hline 22 & Renewable energy & kWh & Available field for entering data from survey \\
\hline 23 & $E_{\mathrm{PDHW}}$ & $\mathrm{kWh} / \mathrm{m}^{2}$ year & $\begin{array}{l}\text { Primary energy for DHW supply calculated on the basis of } \\
\text { standard use conditions }\end{array}$ \\
\hline 24 & $E_{\mathrm{PH}}$ real & $\mathrm{kWh} / \mathrm{m}^{2}$ year & $\begin{array}{l}\text { Available field for entering the primary energy for space heating } \\
\text { from energy audit or renergy cadastral }\end{array}$ \\
\hline 25 & Energy class real & - & $\begin{array}{l}\text { Energy class assigned referred to the real } E_{\mathrm{PH}} \text { or from energy } \\
\text { cadastral }\end{array}$ \\
\hline 26 & $E_{\mathrm{PH}}$ forecasted & $\mathrm{kWh} / \mathrm{m}^{2}$ year & Calculated by tools \\
\hline 27 & Energy class supposed & - & Energy class assigned referred to the ideal $E_{\mathrm{PH}}$ \\
\hline 28 & Electrical consumption & kWh & Available field for entering data from energy audit \\
\hline
\end{tabular}

Table 1. Data recorded in the database 
Engineering Sustainability

Volume 170 Issue ES1
A geographic information method for

managing urban energy use

Gagliano, Nocera, Detommaso and Spataru

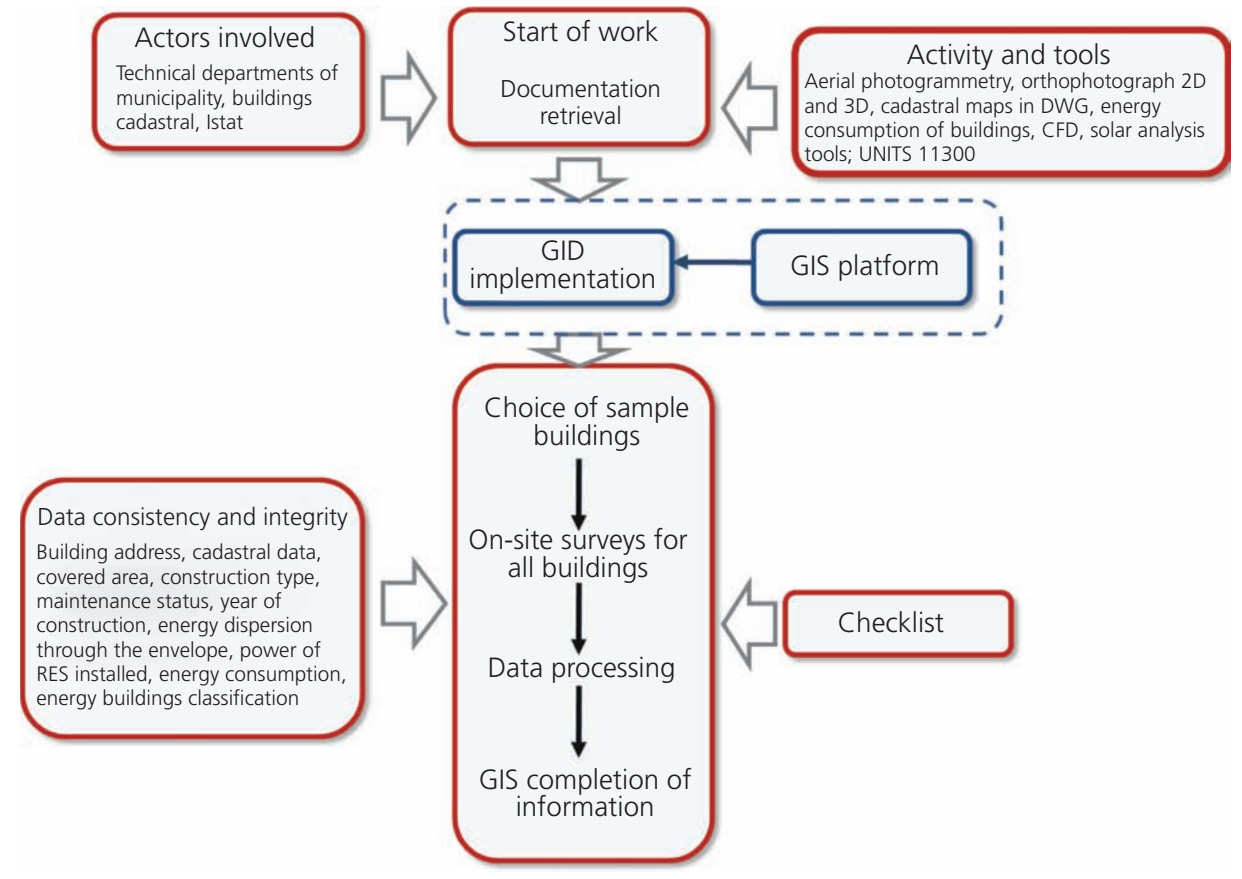

Figure 2. Flowchart of the procedure

guidelines (UNI, 2008a, 2008b, 2010). However, direct survey on sample buildings is very useful for completing and testing the reliability of the collected data.

Table 1 reports an example of the information that can be gathered in the GIS platform.
Many of the parameters in Table 1 can be supplied by the user if they are available. In addition, it is possible to implement algorithms that allow elaboration of the available data.

Figure 2 summarises the different steps followed for developing the proposed procedure.

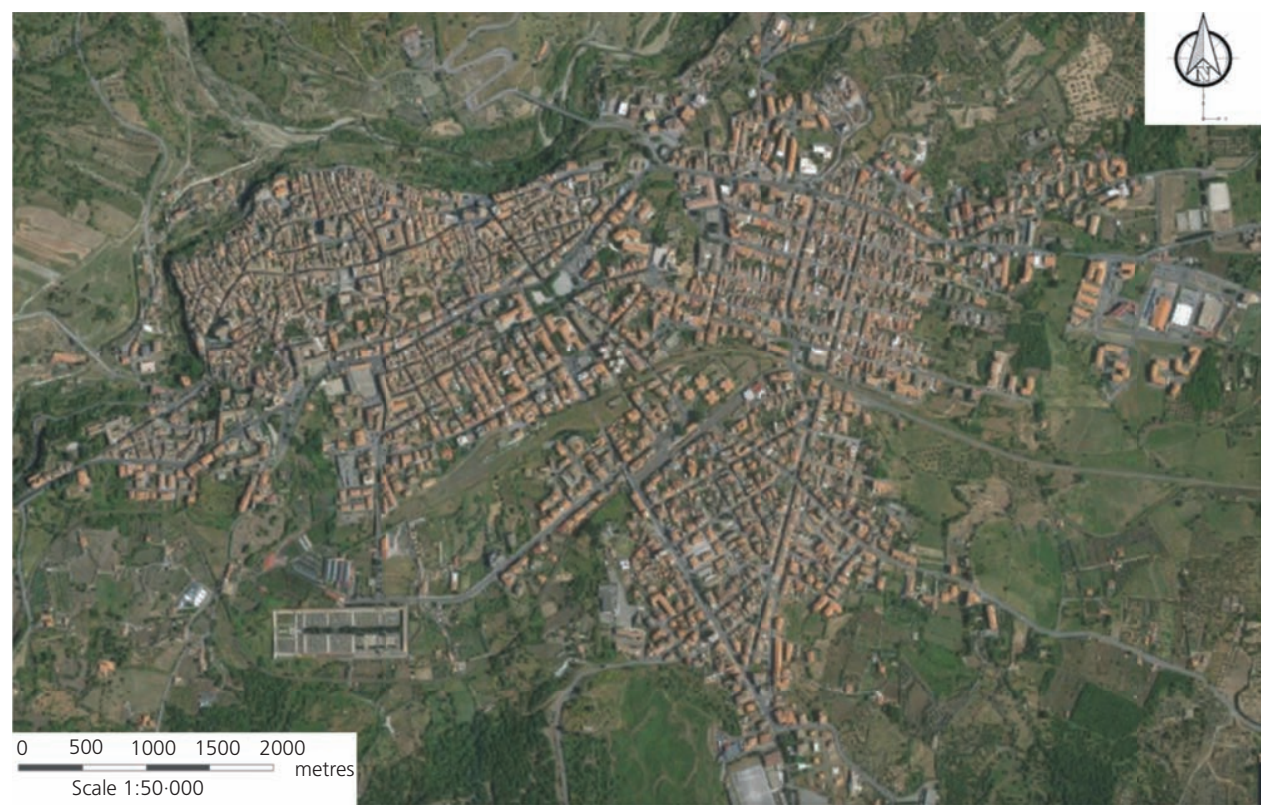

Figure 3. Aerial photograph of Randazzo 


\begin{tabular}{lll} 
Data & Value & \multicolumn{1}{c}{ Unit } \\
\hline Surface & 208.84 & $\mathrm{~km}^{2}$ \\
Inhabitants & 11019 & - \\
Population density & $52 \cdot 76$ & Inhabitants $/ \mathrm{km}^{2}$ \\
Degree day year & 1934 & - \\
Climatic zone & $\mathrm{D}$ & - \\
Average annual temperature & 13.92 & ${ }^{\circ} \mathrm{C}$ \\
Average annual irradiance & 1880 & $\mathrm{kWh} / \mathrm{m}^{2}$ \\
Prevailing wind direction & West & - \\
Wind speed & 4.40 & $\mathrm{~m} / \mathrm{s}$ \\
Relative humidity & $73 \%$ & -
\end{tabular}

Table 2. General data on Randazzo

The first step in the procedure consists of linking the retrieved data with the geo-referenced map.

The progressive updating, coming from direct survey, allows enriching the quality of the database and improves the reliability of the computed indicators. Such preliminary phase of data retrieving and gathering into the GIS platform allows attributing to each building its specific consumption and, if present, the production of renewable energy. Then, it is possible to update the energy needs (e.g. subsequent intervention of energy retrofit) and revise the inventory of annual carbon dioxide emissions as requested by the SEAP.

Moreover, the management of the stored data allows recognising how external variables give an unexpected impact on energy use, both positively and negatively. These figures allow asserting that the proposed methodology could help local communities to make decisions for estimating and monitoring the energy end uses in city territory (residential, commercial, industrial, transport) and to simulate effects of energy policies.

\section{Developing SEAP for Randazzo municipality}

The municipality of Randazzo is one of the 1837 Italian municipalities that are signatories to CoM; it formally adopted its SEAP on 21 January 2015, which received final approval from the Joint Research Centre (JRC) at the end of 2015.

Randazzo has 11019 inhabitants and is situated at the northern foot of the volcano Etna $\left(37^{\circ} 52 \cdot 37^{\prime} 56 \mathrm{~N}, 14^{\circ} 57 \cdot 1^{\prime} 80 \mathrm{E}\right.$; altitude
$765 \mathrm{~m}$ ), $70 \mathrm{~km}$ northwest of Catania (see Figure 3). Table 2 summarises the general information on the municipality of Randazzo.

The degree days are calculated through the sum extended to every day of an annual conventional heating period, of the positive differences between the indoor temperature and the mean daily external temperature.

Table 3 reports the classification of the buildings stock according to their period of construction.

Among 5884 buildings, 4468 (75\%) are residential buildings with a floor area of $411524 \mathrm{~m}^{2}$. Approximately $94 \%$ of the building stock is equipped with a heating system for DHW production and/ or space heating. Considering that $21 \cdot 1 \%$ of the buildings constructed before 1981 require substantial maintenance (Corrado et al., 2014), it is possible to highlight that about 800 buildings need a very important energy revamping.

\subsection{Baseline emission inventory}

Energy consumption and carbon dioxide emissions are dependent on many factors: level of economic activity, population, density, characteristics of the building stock, usage and development of the transport modes, citizens' attitudes, climate and so on (Spataru and Gauthier, 2014).

The BEI must cover the key sectors of activity (at least three or four key sectors). In order to carry out the BEI of the Randazzo municipality, the necessary information was retrieved from several sources: Regional Informative System for Environment and Energy, the national census database (Istat years 2001, 2006, 2012), direct survey, housing municipal departments and so on.

Figure 4 shows the energy consumption of the municipality, classified according to the sectors of public utility, public buildings, residential buildings, public transport, private transport, tertiary and productive (industry). Particularly, the energy consumptions of the public sectors were obtained through the direct survey of the energy bills over a 3-year period.

As regards the residential building sector, the specific energy demand per unit of floor area $\left(\mathrm{kWh} / \mathrm{m}^{2}\right.$ year) was estimated preliminarily through both survey and statistical data. Then, the energy requirements were calculated by multiplying the specific energy demand by the building's floor area. The energy

\begin{tabular}{lcccccr}
\hline Building & Before 1919 & $1919-1945$ & $1946-1961$ & $1962-1981$ & $1982-1991$ & Post-1991 \\
\hline Number & 386 & 641 & 1288 & 1544 & 396 & 213 \\
Percentage & 8.63 & 14.35 & 28.83 & 34.56 & 8.86 & 4.77
\end{tabular}

Table 3. Classification of the existing buildings 


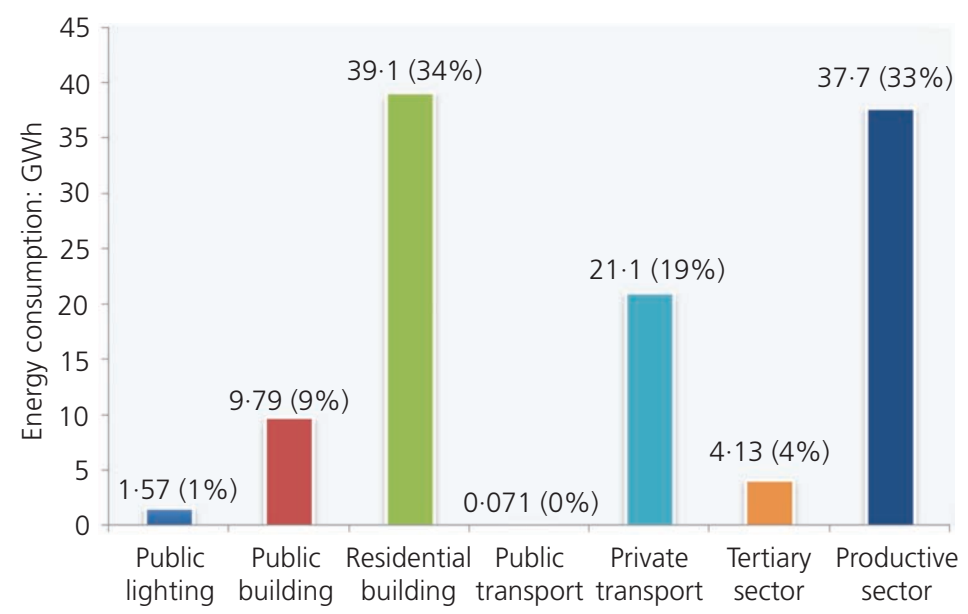

Figure 4. Energy requirement by sector

requirements of the other sectors were obtained from the available statistical data. Therefore, the total yearly energy demand of the municipality is $113.51 \mathrm{GWh}$. Starting from this value, the per capita energy requirement is $10.06 \mathrm{MWh}$, which is about $30 \%$ of the national energy consumption per capita, which is approximately $34 \cdot 77 \mathrm{MWh}$ (Ispra, 2013).

The modest energy usage is certainly due to both the modest standard of living of the citizens of Randazzo and the scarcity of industrial activities.

Figures 4 and 5 show respectively the energy requirements by sector and by each energy source.
The sector 'residential buildings' is the sector with the highest energy consumption, as it is responsible for $39 \cdot 1 \%$ of the whole energy requirement.

Table 4 shows the comparison between the percentage of final energy consumption for the sectors reported in the BEIs for Randazzo and the EU-28 (European Commission, 2015).

It is possible to highlight substantial differences for the residential building sector due to the energy-inefficient building envelopes and outdated equipment systems. Consequently, there is great scope for reducing the energy requirements of this sector. Moreover, the public lighting of Randazzo is responsible for

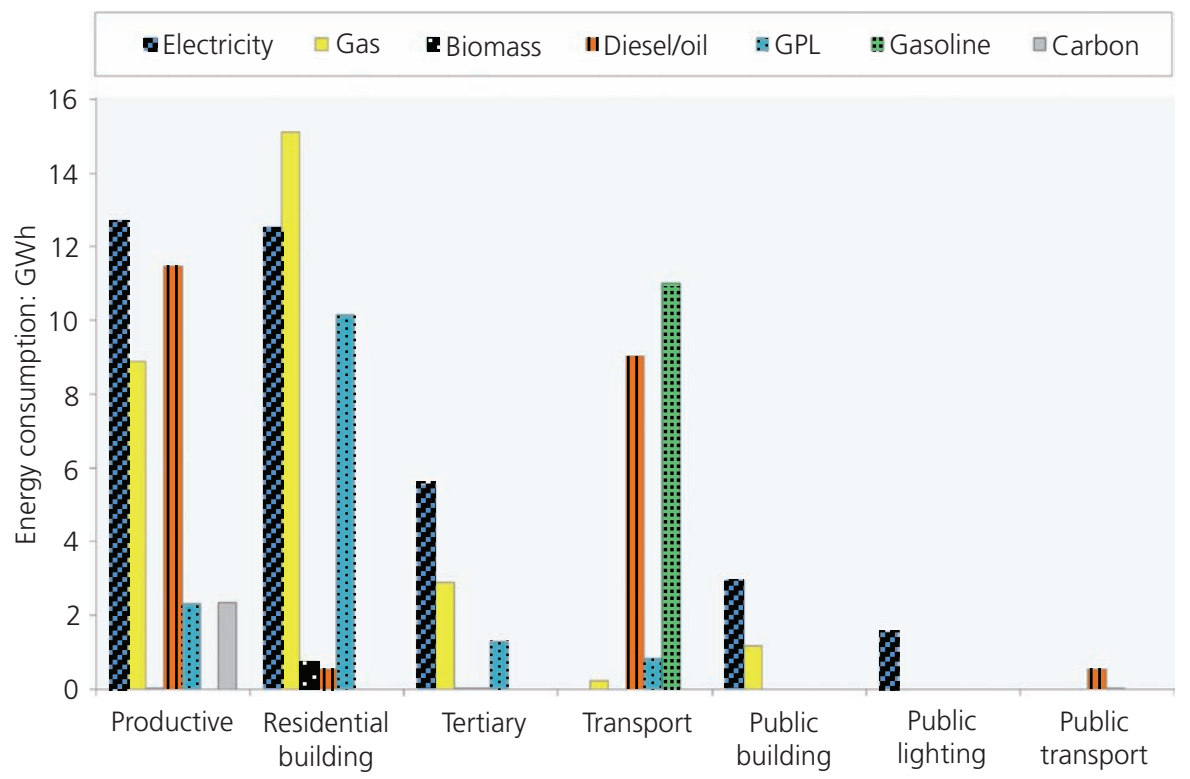

Figure 5. Energy requirement by energy source 


\begin{tabular}{|c|c|c|c|}
\hline & Sectors covered & $\begin{array}{l}\text { Percentage of final } \\
\text { energy consumption } \\
\text { in EU-28: \% }\end{array}$ & $\begin{array}{l}\text { Percentage of final } \\
\text { energy consumption } \\
\text { in Randazzo: \% }\end{array}$ \\
\hline \multirow{7}{*}{$\begin{array}{l}\text { Buildings, equipment, facilities } \\
\text { and industries }\end{array}$} & Municipal buildings, equipment, facilities & 1.83 & $3 \cdot 54$ \\
\hline & Tertiary buildings, equipment, facilities & $11 \cdot 69$ & 8.62 \\
\hline & Residential buildings & $28 \cdot 55$ & $34 \cdot 43$ \\
\hline & Municipal public lighting & $0 \cdot 27$ & $1 \cdot 38$ \\
\hline & Industries (non-emission trading scheme) & $12 \cdot 22$ & $21 \cdot 14$ \\
\hline & Not assigned in the macro-sector & $16 \cdot 07$ & $12 \cdot 00$ \\
\hline & Subtotal & $70 \cdot 63$ & $81 \cdot 32$ \\
\hline \multirow[t]{6}{*}{ Transport } & Municipal fleet & $0 \cdot 16$ & 0.05 \\
\hline & Public transport & 0.94 & - \\
\hline & Private and commercial transport & $19 \cdot 28$ & $18 \cdot 59$ \\
\hline & Not assigned in the macro-sector & 8.98 & - \\
\hline & Subtotal & $29 \cdot 37$ & $18 \cdot 68$ \\
\hline & Total & $100 \cdot 00$ & $100 \cdot 00$ \\
\hline
\end{tabular}

Table 4. Rate of final energy consumption

$1 \cdot 38 \%$ of the total energy consumption, which is higher than the consumption of such a facility in the EU-28 countries, which is just $0 \cdot 27 \%$.

This result indicates the opportunity to reduce the energy consumption of this sector, substituting the outdated equipment and improving its management.

However, national laws usually protect historic buildings so that the number of options to reduce energy consumption is quite restricted.

The BEI of Randazzo, for the reference year 2011, was calculated by using the Italian GHG inventory (World Bank, 2016).
In addition, the emissions from road transport made by Institute for Environmental Protection and Research that provides provincial emissions into the atmosphere classified by activity level based on Selected Nomenclature for Air Pollution-Core Inventory Air Emissions (Snap-Corinair), was done through disaggregation of the national inventory, adopting a top-down approach.

Afterwards, it was possible to evaluate $34317 \mathrm{t} /$ year of carbon dioxide emissions ( $3 \cdot 11 \mathrm{t} /$ capita). Figures 6 and 7 show respectively the carbon dioxide emissions by sector and by energy source.

\subsection{Actions and target}

The knowledge of the share of the economic sectors in the total energy requirements allows the municipality to define priorities

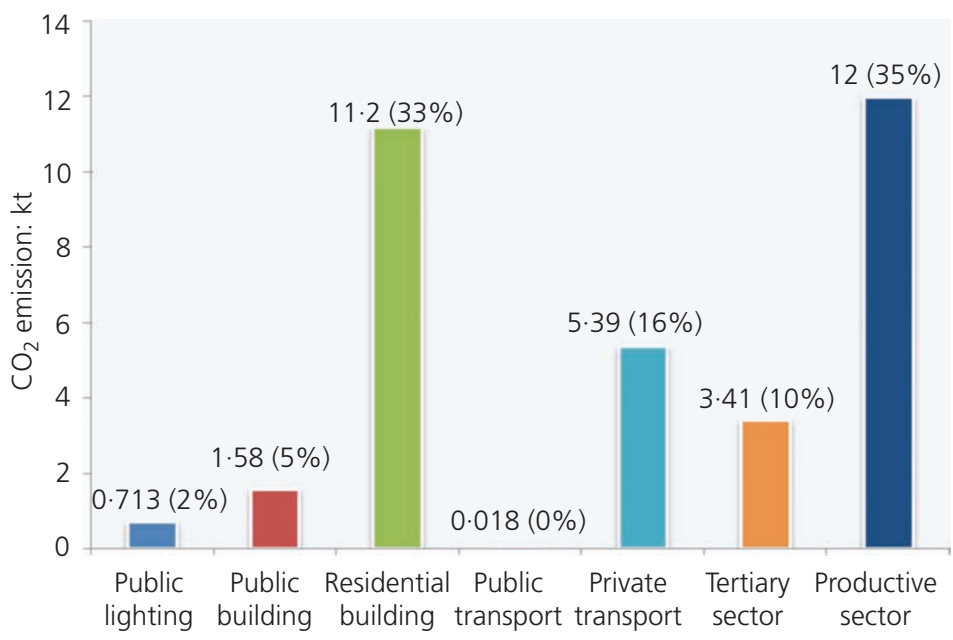

Figure 6. Annual carbon dioxide emission by sector 


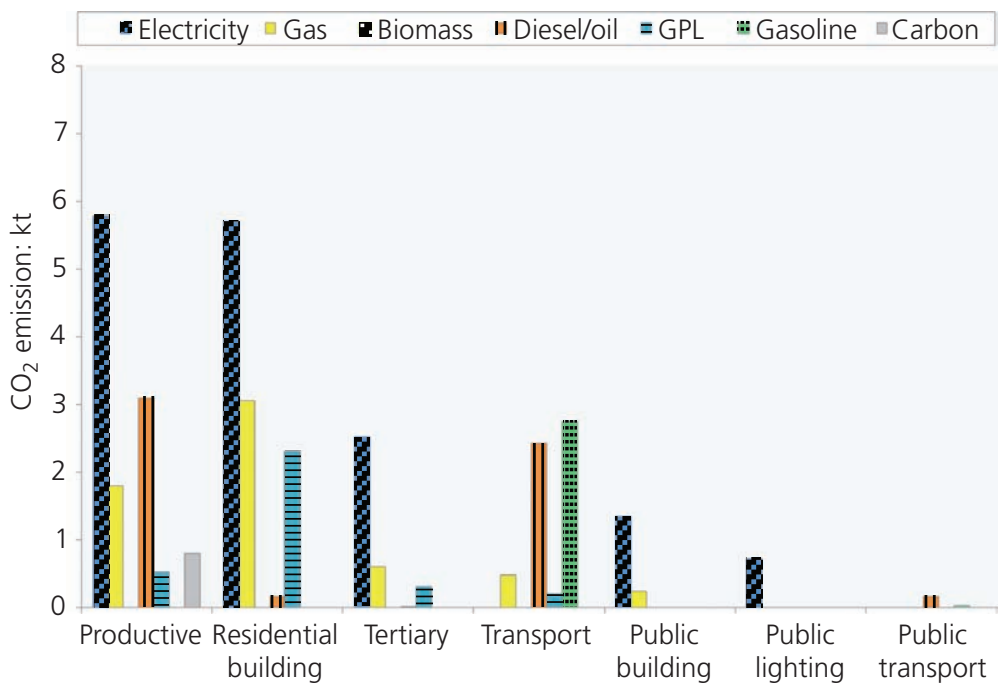

Figure 7. Carbon dioxide emission by energy source

and select relevant measures in order to cut the carbon dioxide emissions.

Starting from this figure, it was planned the actions to achieve the objective of at least $20 \%$ reduction by 2020 .

Thus, a set of energy actions were planned for the main sectors, buildings and public services, private buildings, transport, tertiary and industry, for which the authors have developed an analysis of energy efficiencies and vulnerability. In the following, the authors propose a summary of the foreseen actions for each sector.

\subsubsection{All sectors}

- Create an info portal on the renewable energies and energyefficiency sectors, with practical and timely information for citizens (e.g. where to buy biomass, identify areas suitable for installing wind turbine or solar thermal/PV plants, list of installers and equipment, stimulate collective buying).

- Provide information and support to stakeholders.

- Furthermore, a web interface is useful to inform citizens on the energy consumption of their communities and encourage them to perform sustainable actions in their own houses or work activities.

\subsubsection{Municipal buildings, equipment and facilities}

- Increase the performance of the building envelope of the entire building stock. Such an action foresees an energy saving of about $195 \cdot 00 \mathrm{MWh} /$ year.

- Increase the efficiency, quality of the regulation and maintenance of the technical installations for heating, cooling, ventilation and humidity control. Such an action foresees an energy saving of about $160 \cdot 00 \mathrm{MWh} /$ year.
- Increase the renewable energy production through PV and solar thermal plants: energy yield of about $170.00 \mathrm{MWh} /$ year.

- Install a mini-hydroelectric plant with a capacity of $158 \mathrm{~kW}$ on the water pipeline called 'San Giacomo,' which has a height difference of $450 \mathrm{~m}$. Such intervention foresees an energy production of $86.4 \mathrm{MWh}$.

- Install mini-wind turbines at the sewage treatment plant water: total power of $45 \mathrm{~kW}$ peak $(\mathrm{kWp})$ and energy yield of 100.0 MWh.

- Install an anaerobic digester of municipal wastewater sludge for the production of biogas: energy yield of $20.0 \mathrm{MWh}$.

- Reduce water leakage in the public water systems. Such intervention will allow obtaining an energy saving of $367 \cdot 52 \mathrm{MWh} /$ year.

- Plant new arboreal vegetation (P10).

\subsubsection{Tertiary buildings}

It was agreed to boost the installation of renewable energy plants, especially PV systems. The municipality will provide information to business owners, support them and facilitate procedures and will promote collective buying. Globally, about $110.0 \mathrm{kWp}$ of new plants is foreseen, which produces about $150 \cdot 0 \mathrm{MWh} /$ year of electrical energy (TER1).

\subsubsection{Residential buildings}

- Increase the performance of both the building envelope of existing buildings and the efficiency, quality of the regulation and maintenance of the technical installations for heating, cooling, ventilation and humidity control. Such an action foresees an energy saving of about $2000.00 \mathrm{MWh} /$ year, which is about $10 \%$ of the current demand thermal energy (RB1 and RB2).

- Reduce electricity consumption through the installation of energy-efficient light, appliances, building automation systems 
and so on. Such an action foresees an energy saving of about $1300.00 \mathrm{MWh} /$ year, which is about $10 \%$ of the current demand for electrical energy (RB3 and RB4).

- Increase the renewable energy production through PV plants. Installation of about $1.50 \mathrm{MWp}$ of PV plants is foreseen, or about 500 new plants with a nominal power of $3 \mathrm{kWp}$ each. The energy yield is about $2000 \cdot 00 \mathrm{MWh} /$ year (RB5).

- Increase the renewable energy production through solar thermal plants. Installation of about $1500 \mathrm{~m}^{2}$ of solar thermal collector is foreseen. The energy yield is about 1200.00 MWh/year (RB6). These two actions (RB5 and RB6) will be supported by the municipality simplifying access at already available feed-in tariff, which is used to encourage deployment of renewable technologies, and also by launching collective buying.

\subsubsection{Productive}

- Boost the installation of PV plants by providing information and support to stakeholders and promoting collective buying. Globally, the installation of about $1 \cdot 10 \mathrm{MWp}$ of new plants (about 60 new plants with a nominal power of $<20 \mathrm{kWp}$ ) is foreseen, which produces about $1500 \mathrm{MWh} /$ year of electrical energy (PR1).

- Moreover, the installation of cogeneration systems with sizes between 30.0 and $50.0 \mathrm{~kW}$ was considered, for the

\begin{tabular}{|c|c|c|c|c|}
\hline Sector & Type & ID & Action & $\begin{array}{l}\text { Carbon dioxide } \\
\text { reduction: } t\end{array}$ \\
\hline \multirow[t]{4}{*}{ All sectors } & \multirow[t]{4}{*}{ Information } & INF1 & Energy guardians & $4 \cdot 85$ \\
\hline & & INF2 & Energy information & $21 \cdot 12$ \\
\hline & & INF3 & Electrical counter meter & $75 \cdot 36$ \\
\hline & & INF4 & Thermal counter meter & $54 \cdot 58$ \\
\hline \multirow{10}{*}{$\begin{array}{l}\text { Municipal and tertiary } \\
\text { buildings, equipment, } \\
\text { facilities }\end{array}$} & Building envelope & PA1 & Improvement of thermal insulation & $33 \cdot 04$ \\
\hline & \multirow[t]{7}{*}{ Generator/RES } & PA2 & Opportunities for energy savings & $7 \cdot 37$ \\
\hline & & PA3 & Replacement of old heating plants & $35 \cdot 76$ \\
\hline & & PA4 & Installation of PV plants on public buildings & $79 \cdot 45$ \\
\hline & & PA5 & Micro-hydropower plant & $432 \cdot 58$ \\
\hline & & PA6 & Micro-wind turbine & $91 \cdot 03$ \\
\hline & & PA7 & Solar thermal & $30 \cdot 23$ \\
\hline & & PA8 & Energy exploitation of sewage sludge & $18 \cdot 20$ \\
\hline & \multirow[t]{2}{*}{ Other } & PA9 & Reducing water requirements & $167 \cdot 28$ \\
\hline & & PA10 & New arboreal vegetation & $12 \cdot 44$ \\
\hline Tertiary & RES & TER1 & RES on tertiary building & $216 \cdot 97$ \\
\hline \multirow[t]{6}{*}{ Residential buildings } & \multirow[t]{2}{*}{ Energetic class } & RB1 & $\begin{array}{l}\text { Increase the performance of both the building } \\
\text { envelope of existing buildings and the efficiency of } \\
\text { the technical installations }\end{array}$ & $414 \cdot 69$ \\
\hline & & RB2 & Improvement of the energy class of new buildings & $41 \cdot 5$ \\
\hline & \multirow[t]{2}{*}{ Electric consumption } & RB3 & Installation of energy-efficient light, appliances & $532 \cdot 5$ \\
\hline & & RB4 & Building automation & $91 \cdot 3$ \\
\hline & \multirow[t]{2}{*}{ RES } & RB5 & Installation of new PV plants $(P<20 \mathrm{~kW})$ & $1820 \cdot 62$ \\
\hline & & RB6 & Installation of new solar thermal plants & 498 \\
\hline \multirow[t]{2}{*}{ Industry } & RES & PR1 & Installation of PV plants & 1364 \\
\hline & Cogeneration & PR2 & Energy recovery of waste wood biomass & $342 \cdot 12$ \\
\hline \multirow[t]{3}{*}{ Public lighting } & & IP1 & $\begin{array}{l}\text { Substitution of mercury lamps with most efficient } \\
\text { lamps }\end{array}$ & $77 \cdot 87$ \\
\hline & & IP2 & Lighting management systems & $145 \cdot 65$ \\
\hline & & IP3 & Light-emitting diode lamps for cemetery & $44 \cdot 26$ \\
\hline \multirow[t]{3}{*}{ Transport } & \multirow{3}{*}{$\begin{array}{l}\text { Private and } \\
\text { commercial transport }\end{array}$} & TR1 & Improvement of ICTS & $20 \cdot 41$ \\
\hline & & TR2 & $\begin{array}{l}\text { Increasing the attractiveness of 'alternative' } \\
\text { transport modes }\end{array}$ & $78 \cdot 90$ \\
\hline & & TR3 & Reducing vehicle fleet emissions & $447 \cdot 16$ \\
\hline
\end{tabular}

Table 5. Action planned for each sector 
production of thermal and electrical energy from woodchips.

Globally, an annual energy production of $750 \cdot 0 \mathrm{MWh}$ (PR2)

is foreseen.

\subsubsection{Public lighting}

The authors selected the following measures that should allow a powerful energy saving: installation of energy-efficient lighting; reduction of lighting levels or switching off the installation after certain hours at night, through street lighting management systems; and efficient management of cemetery light. These actions (IP1, IP2 and IP3) will allow an energy saving of about $588 \cdot 0 \mathrm{MWh}$ to be obtained.

\subsubsection{Transport}

Considering the actual state of this sector, the following measures have been scheduled

- reducing the need for transport and strengthening the use of information and communication technologies (ICTs) by implementing online administrative procedures and citizens avoiding travelling to fulfil their duties with public administration (TR1)

- increasing the attractiveness of 'alternative' transport modes through the modal share for walking, cycling and public transport (TR2)

- reducing municipal and private vehicle fleet emissions by using hybrid or other highly efficient technologies; the introduction of alternative fuels and promoting efficient driving behaviour (TR3) (Patania et al., 2003).

Globally these actions will contribute $546 \mathrm{t}$ of carbon dioxide emission reductions, which constitutes about $10 \%$ of the total emissions of this sector.

Table 5 summarises all the proposed actions for each sector.
Figure 8 summarises, for each action, the energy savings, carbon dioxide emission reductions and renewable energy yield forecasted in the residential sector.

All the actions proposed will allow reducing the energy consumption by about $14.52 \mathrm{MWh}$, which is about $12.0 \%$ of the current energy consumption. It was also discussed that the production of renewable energy should increase from the current 13.0 to $5977.0 \mathrm{MWh}$; in such a way, about $6.0 \%$ of the energy requirement will be obtained from RES. That share is higher than the mean value of $4 \%$ estimated for the other municipalities in the EU-28.

As result, $7118 \mathrm{t}$ of carbon dioxide emissions is avoided, with a reduction of $20.7 \%$, passing from $34317 \mathrm{t}$ of carbon dioxide in 2011 to $27199 \mathrm{t}$ of carbon dioxide in 2020 . Therefore, the requested target will be satisfied.

Obviously, all the proposed actions need to be supported through adequate financial support.

Currently, there are many actions that support the energy retrofit of existing building such as $65 \%$ tax deduction for energyefficiency measures, the so-called conto termico that incentivises the installation of solar thermal panels, heat pumps, heat generators powered by biomass and so on.

Moreover, the region of Sicily will have a leverage of approximately €519.5 million of community aid (POR 2014-2020 FESR) that could be dedicated to support the actuation of the SEAPs.

With reference to the agricultural sector, the authors have to mention the rural development programme (PSR Sicilia 2014-2020), which incentivises the introduction of innovative

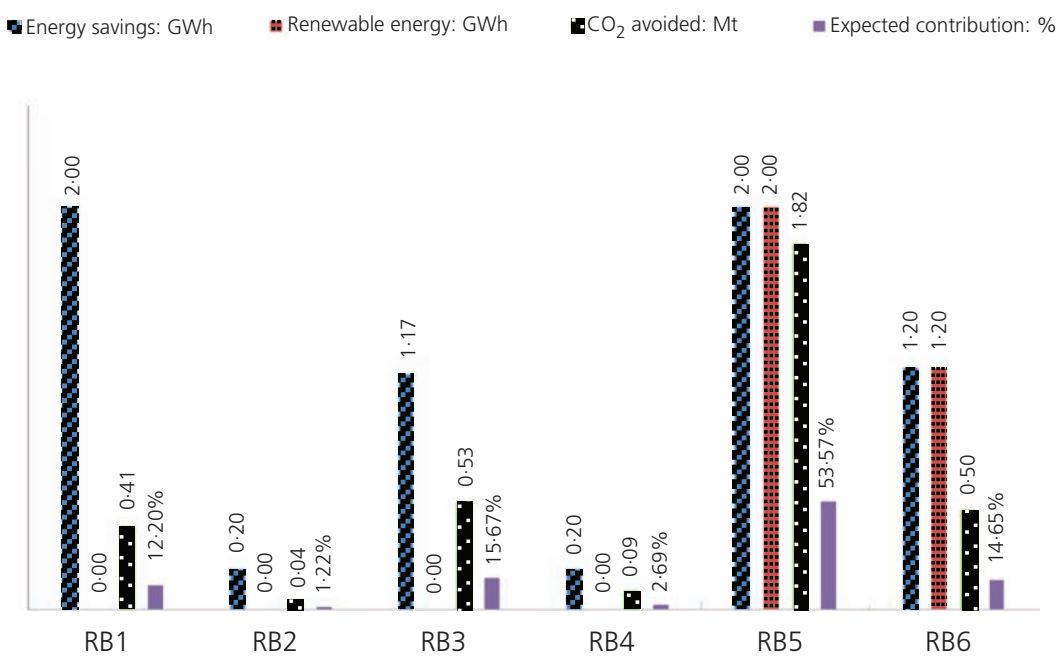

Figure 8. Intervention planned in the residential building sector 
A geographic information method for

managing urban energy use

Gagliano, Nocera, Detommaso and Spataru

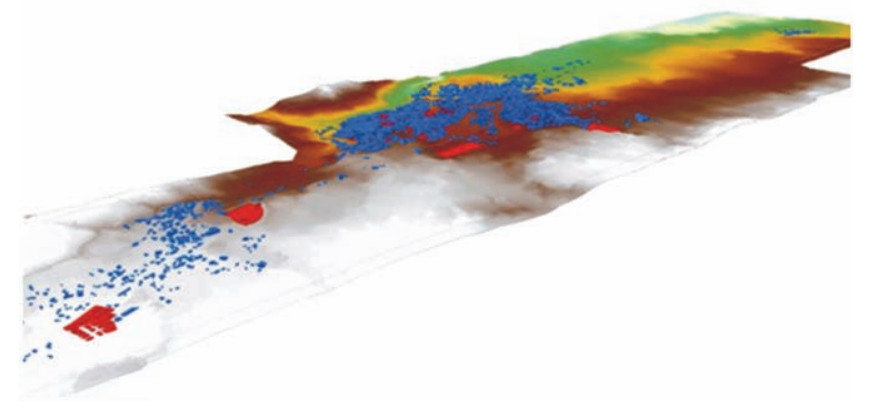

Figure 9. View in ArcMap of the aerial photograph of Randazzo

technologies aimed at energy saving and the exploitation of energy from renewable sources (about $€ 2200$ million).

\section{SEAP and GIS database}

The GIS software ArcGIS 10.1 allows the storage, display, editing, sharing and analysis of the geographical information necessary for developing the SEAP for Randazzo.

The application ArcScene was implemented to build threedimensional (3D) models of the 5884 buildings currently situated in the Randazzo municipality. Aero-photogrammetry, cadastral maps and aerial photographs were imported from the geodatabase. After that, the authors obtained the shapefile of the urban aggregate. The 3D model of the city of Randazzo was obtained by importing the shapefile with the software Google SketchUp Pro 8. Figure 9 shows the view in ArcMap of the aerial photograph of Randazzo with the public buildings shown in red.

Further, starting from the 3D model of the urban area, the solar radiation incident on any building surface was calculated through the 'Solar Radiation Area' function, which is a sub-application of the 'Solar Analyst' tool. This tool uses point-based imagery of local level elevation, slope and aspect to determine the amount of energy available.

The 3D model of the urban area reduces the difficulty of quantifying the available rooftop area because it is directly calculated by the tools. In any case, in order to take into account the effects of shadows generated by objects, or by the roof configuration itself, and to exclude surfaces that have other specific applications (e.g. aerials, stacks or heating, ventilating and air-conditioning equipment), it is necessary to introduce corrective coefficients (Izquierdo et al., 2008).

The data related to the slope of pitched roofs are not directly obtainable from the aerial photogrammetry since the heights of gutters and hipped roofs are not evaluable. Therefore, it is necessary to develop a procedure that allows the identification of the geometry of roofs in residential areas (Massimo et al., 2014).

Optimised algorithms account for variations in surface orientation and atmospheric weather data. Total global solar radiation $\left(R_{\text {Globaltot }}\right)$ was calculated by summing the direct and diffuse radiation, coming from all the sky sectors, on the topographic surface. This application provides as output the irradiance map over the studied area.

Figure 10 shows the map of the global solar radiation expressed in watt-hours per square metre $\left(\mathrm{Wh} / \mathrm{m}^{2}\right)$ for a portion of territory.

Thus, for each building, information on activities was retrieved from the different sources (database, surveying, elaboration through tool and so on) and stored in the GIS platform.

As an example, the tool using the $S / V$ ratio and the number of degree days calculates the law threshold of the allowable primary energy consumption $\left(E_{\mathrm{P}}\right)$, in kilowatt-hours per square metre, of each building.

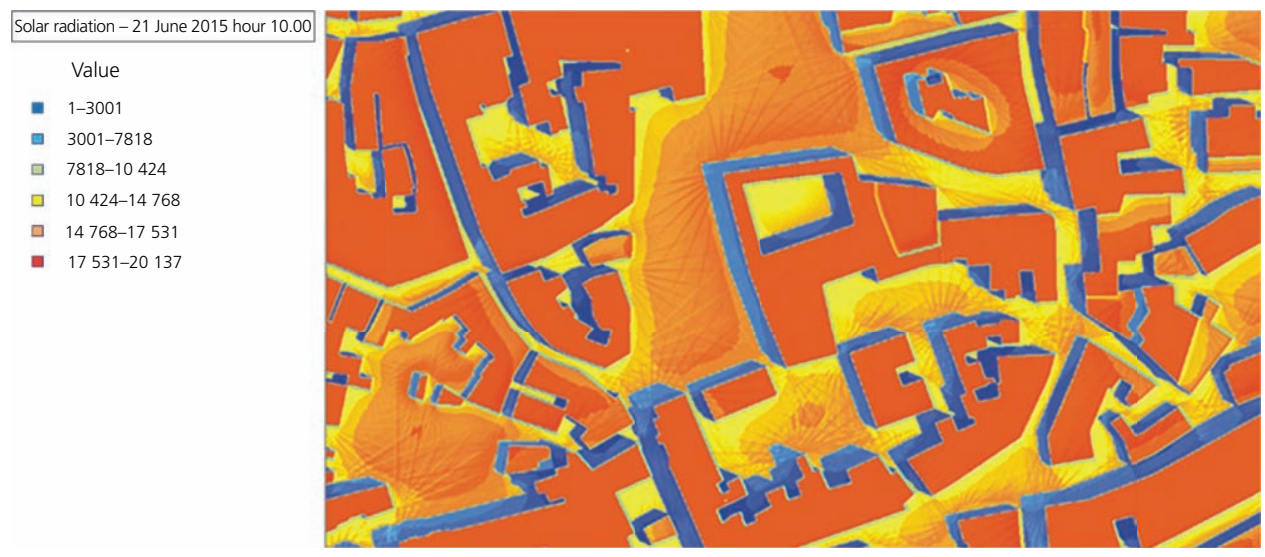

Figure 10. Map of $R_{\mathrm{Globaltot}}$ on 21 June 2015 at 10.00 a.m. 


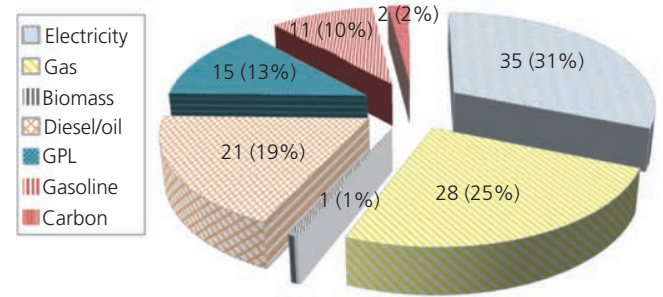

(a)

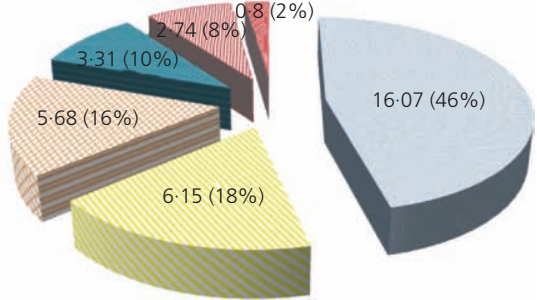

(b)

Figure 11. Total (a) energy consumptions (GWh) and (b) carbon dioxide emission $(k t)$ for different energy sectors

Therefore, for each field listed in Table 1, it is possible to produce thematic geo-referenced maps that show the value of that parameter within the Randazzo territory (e.g. data on energy consumption, energy classification buildings where PV plant are installed).

As regards the energy requirements, the GIS platform allows the progress of the proposed interventions to be monitored and alternative scenarios to be developed. Moreover, it is possible to highlight the current energy consumption for each sector and energy source (Figure 11).

Therefore, the GIS platform provides the urban energy inventory for the whole municipality. However, the database has to be continuously updated to editing the evolution in any of the programmed interventions. In such a way, it will be possible to display, share, analyse and monitor the state of actuation of the SEAP actions.

Figure 12 illustrates the expected and fulfilled amount of energy saving $\left(E_{\mathrm{S}}\right)$ and installed power of renewable energy for the scheduled actions in the residential sector, at the current state.
Only the action RB5 is partially actuated as there are about $140 \mathrm{PV}$ plants already installed with an energy yield of $730 \mathrm{MWh} /$ year. From now until 2020, the administration must update the progress in the fulfilment of each programmed action. Therefore, it will be possible to monitor each planned intervention, verifying the advance of its state of actuation with respect to the scheduled time. As a consequence of this analysis, the city administration identifies actions that have been highly effective and uses these as benchmarks of excellence in the respective sectors, or highlights initiatives that have not progressed as planned and seeks to rectify this matter.

Understanding these interactions will allow for a more efficient integration of activities and sustainable energy measures and the development of synergies within the SEAP and the urban development strategy.

\section{Conclusions}

A GIS has been adopted as a tool support for the SEAPs; this GIS permits the identification of actions to reach and control the 2020-20 targets. Starting with information that is already available on the building stock (i.e. cartographic documentation, thematic

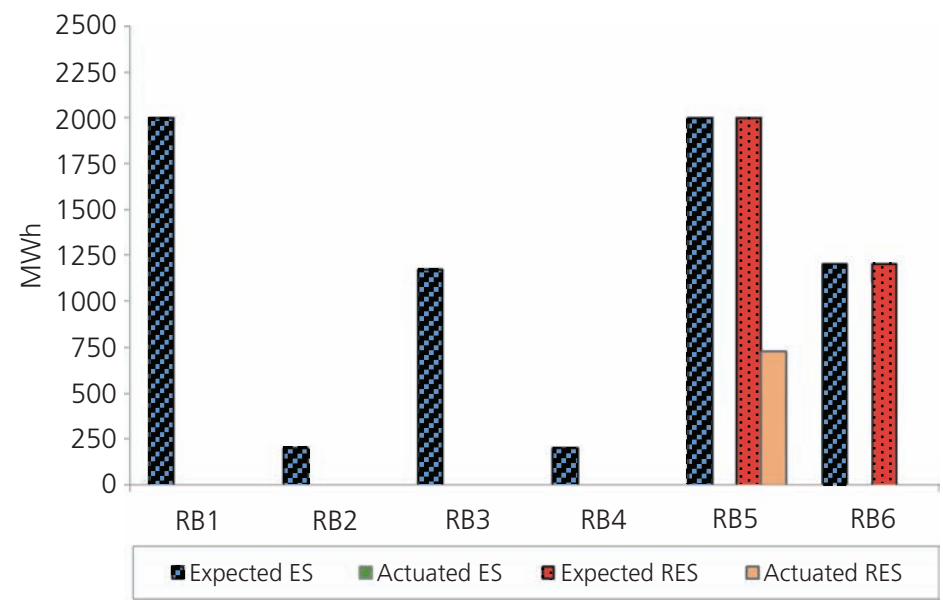

Figure 12. Comparison between programmed and realised actions 
maps, geometric data and others), the GIS has allowed the organisation, systemisation and geo-referencing of all the available data. The spatial geographical energy needs are estimated by using primary data, and when these are not available, statistical values are included.

In this way it is possible to manage the actual building stock energy performances, evaluate the possible effects of energy strategies (e.g. energy saving potentials) and the impact they may have on the territory. In fact, the proposed methodology, thanks to the GIS capabilities, permits an immediate updating of the energy evaluations and offers a clear visualisation of the effects of interventions, giving important support to the involved decision makers.

This will allow the identification and localisation of existing renewable energy resources and energy needs within the urban area. Based on this case study, the adoption of a GIS proved to be a suitable support tool during both phases of elaboration and realisation of the SEAPs. Moreover, it is possible to propose such a methodology for application in different geographical areas or context. Indeed, such a methodology will be able to support energy policies at the urban level and make decisions for estimating and monitoring the energy consumption in buildings (residential, commercial, industrial), taking into account the approaches of different stakeholders to develop low-carbon dioxide models.

\section{Acknowledgements}

The authors would like to acknowledge the municipality of Randazzo for providing them with all the necessary support for the research.

\section{REFERENCES}

Asdrubali F, Presciutti A and Scrucca F (2013) Development of a greenhouse gas accounting GIS-based tool to support local policy making - application to an Italian municipality. Energy Policy 61: 587-594, http://dx.doi.org/10.1016/j.enpol.2013.05. 116.

Brandoni C and Polonara F (2012) The role of municipal energy planning in the regional energy-planning process. Energy 48(1): 323-338, http://dx.doi.org/10.1016/j.energy.2012.06. 061.

Caputo P, Costa G and Ferrari S (2013) A supporting method for defining energy strategies in the building sector at urban scale. Energy Policy 55: 261-270, http://dx.doi.org/10.1016/j.enpol. 2012.12.006.

Cefa (Catasto Energetico Fabbricati) (2016) http://cefa.energia. sicilia.it/ (accessed 22/03/2016).

CoM (Covenant of Mayors) (2016) http://www.covenantofmayors. eu (accessed 22/03/2016).

Comodi G, Cioccolanti L and Gargiulo M (2011) Municipal scale scenario: analysis of an Italian seaside town with MarkALTimes. Energy Policy 41: 303-315, http://dx.doi.org/10.1016/j. enpol.2011.10.049.

Corrado V, Ballarini I and Corgnati SP (2014) Building Typology Brochure. Politecnico di Torino, Torino, Italy.
Dall'O' G, Galante A and Torri M (2012) A methodology for the energy performance classification of residential building stock on an urban scale. Energy and Buildings 48: 211-219, http:// dx.doi.org/10.1016/j.enbuild.2012.01.034.

Dascalaki E, Droutsa K, Gaglia AG, Kontoyiannidis S and Balaras CA (2010) Data collection and analysis of their building stock and its energy performance - an example for Hellenic buildings. Energy and Buildings 42(8): 1231-1237, http://dx. doi.org/10.1016/j.enbuild.2010.02.014.

EC (European Community) (2002) Directive 2002/91/EC of the European Parliament and of the Council of 16 December 2002 on the energy performance of buildings. Official Journal of the European Communities $\mathbf{L 1 6 5 .}$

Energy Cities (2010) EU 2020 Position Paper: Making the Covenant of Mayors a Successful Multilayer Governance test in the Energy and Climate Field. Energy Cities, Brussels, Belgium.

European Commission (2015) http://ec.europa.eu/clima/policies/ package/index_en.htm (accessed 23/04/2015).

European Commission (2016) http://ec.europa.eu/clima/policies/ (accessed 22/03/2016).

Fiaschi D, Bandinelli R and Conti S (2012) A case study for energy issues of public buildings and utilities in a small municipality: investigation of possible improvements and integration with renewables. Applied Energy 97: 101-114, http://dx.doi.org/10.1016/j.apenergy.2012.03.008.

Gagliano A, Nocera F, Patania F and Capizzi A (2013a) Assessment of micro-wind turbines performance in the urban environments: an aided methodology through geographical information systems. International Journal of Energy and Environmental Engineering 4(43): 1-14, http://dx.doi.org/10. 1186/2251-6832-4-43.

Gagliano A, Patania F, Nocera F, Capizzi A and Galesi A (2013b) GIS-based decision support for solar photovoltaic planning in urban environment. In Sustainability in Energy and Buildings: Proceedings of the 4th International Conference in Sustainability in Energy and Buildings (SEB'12) (Hakansson A, Hojer M, Howlett RJ and Jain LC (eds)). Springer, Berlin, Germany, pp. 865-874.

Hou J, Zhang P, Tian Y, Yuan X and Yang Y (2011) Developing low-carbon economy: actions, challenges and solutions for energy savings in China. Renewable Energy 36(11): 1-6, http://dx.doi.org/10.1016/j.renene.2011.03.033.

Ispra (2013) Italian Greenhouse Gas Inventory 1990-2011. National Inventory Report 2013.

Istat (Istituto Nazionale di Statistica) (2016) http://www.istat.it (accessed 22/03/2016).

Izquierdo S, Rodrigues and Fueyo N (2008) A method for estimating the geographical distribution of the available roof surface area for large-scale photovoltaic energy-potential evaluations. Solar Energy 82(10): 929-939, http://dx.doi.org/ 10.1016/j.solener.2008.03.007.

Jones PJ, Lannon S and Williams J (2001) Modelling building energy use at urban scale. Seventh International IBPSA Conference, Rio de Janeiro, Brazil, 13-15 August. 
A geographic information method for

managing urban energy use

Gagliano, Nocera, Detommaso and Spataru
Massimo A, Dell'Isola M, Frattolillo A and Ficco G (2014) Development of a geographical information system (GIS) for the integration of solar energy in the energy planning of a wide area. Sustainability 6(9): 5730-5744, http://dx.doi.org/10. 3390/su6095730.

Patania F, Gagliano A and Nocera F (2003) Air pollution and urban plane of road traffic: experimental research about situations of environmental health hazard. Advances in Transport 14: 253-262, http://dx.doi.org/10.2495/UT030261.

Programma Operativo Sicilia FESR 2014-2020 See http://www. euroinfosicilia.it/programmazione-20142020/ (accessed 22/03/2016).

PSR 2014-2020 Programma di Sviluppo Rurale della Regione Sicilia See http://www.psrsicilia.it/ (accessed 22/03/2016).

Ramachandra TV and Shruthi BV (2007) Spatial mapping of renewable energy potential. Renewable and Sustainable Energy Reviews 11(7): 1460-1480, http://dx.doi.org/10.1016/j. rser.2005.12.002.

SITR (Sistema Informativo Territoriale Regionale) (2016) http:// www.sitr.regione.sicilia.it/content/view/119/129/ (accessed 22/03/2016).

Spataru C and Gauthier S (2014) How to monitor people 'smartly' to help reducing energy consumption in buildings? Architectural Engineering and Design Management 10(1-2): 60-78, http://dx.doi.org/10.1080/17452007.2013.837248.

Sun Y, Hof A, Wang R et al. (2013) GIS-based approach for potential analysis of solar PV generation at the regional scale: a case study of Fujian Province. Energy Policy 58: 248-259, http://dx.doi.org/10.1016/j.enpol.2013.03.002.
Theodoridou I, Papadopoulos AM and Hegger M (2011) Statistical analysis of the Greek residential building stock. Energy and Buildings 43(9): 2422-2428, http://dx.doi.org/10. 1016/j.enbuild.2011.05.034.

Thuvander L (2002) Towards Environmental Informatics for Building Stocks. Department of Built Environment \& Sustainable Development, Chalmers University of Technology, Gothenburg, Sweden.

Tommerup H and Svendsen S (2006) Energy savings in Danish residential building stock. Energy and Buildings 38(6): 618-626, http://dx.doi.org/10.1016/j.enbuild.2005.08.017.

Tornberg J and Thuvander L (2005) A GIS model for the building stock of Goteborg. Proceedings of the 25th Annual ESRI User Conference.

UNI (Ente Nazionale Italiano di Unificazione) (2008a) UNI TS 11300-1: Prestazioni energetiche degli edifici - parte 1: Determinazione del fabbisogno di energia termica dell'edificio per la climatizzazione estiva ed invernale. UNI, Milan, Italy.

UNI (2008b) UNI TS 11300-2: Prestazioni energetiche degli edifici - parte 2: Determinazione del fabbisogno di energia primaria e dei rendimenti per la climatizzazione invernale e per la produzione di acqua calda sanitaria. UNI, Milan, Italy.

UNI (2010) UNI TS 11300-3: Prestazioni energetiche degli edificiparte 3: Determinazione del fabbisogno di energia primaria e dei rendimenti per la climatizzazione estiva. UNI, Milan, Italy.

World Bank (2016) http://data.worldbank.org/indicator/ (accessed 22/03/2016)

\section{HOW CAN YOU CONTRIBUTE?}

To discuss this paper, please email up to 500 words to the editor at journals@ice.org.uk. Your contribution will be forwarded to the author(s) for a reply and, if considered appropriate by the editorial board, it will be published as discussion in a future issue of the journal.

Proceedings journals rely entirely on contributions from the civil engineering profession (and allied disciplines). Information about how to submit your paper online is available at www.icevirtuallibrary.com/page/authors, where you will also find detailed author guidelines. 